\title{
Betacellulin and Activin A Coordinately Convert Amylase-secreting Pancreatic AR42J Cells into Insulin-secreting Cells
}

\author{
Hirosato Mashima, ${ }^{*}$ Hirohide Ohnishi, ${ }^{\star}$ Katsumi Wakabayashi, ${ }^{\star}$ Tetsuya Mine, ${ }^{\ddagger}$ Jun-ichiro Miyagawa, ${ }^{\S}$ Toshiaki Hanafusa, ${ }^{\S}$ \\ Masaharu Seno," Hidenori Yamada, $\|$ and Itaru Kojima* \\ *Institute for Molecular and Cellular Regulation, Gunma University, Maebashi 371; ${ }^{\ddagger}$ Fourth Department of Internal Medicine, University \\ of Tokyo School of Medicine, Tokyo 112; ${ }^{\S}$ Second Department of Internal Medicine, Osaka University Medical School, Osaka 565; and \\ Department of Bioengineering Science, Faculty of Engineering, Okayama University, Okayama 700, Japan
}

\begin{abstract}
Rat pancreatic AR42J cells possess exocrine and neuroendocrine properties. Activin A induces morphological changes and converts them into neuron-like cells. In activin-treated cells, mRNA for pancreatic polypeptide (PP) but not that for either insulin or glucagon was detected by reverse transcription-PCR. About $25 \%$ of the cells were stained by antiPP antibody. When AR42J cells were incubated with betacellulin, a small portion of the cells were stained positively with antiinsulin and anti-PP antibodies. The effect of betacellulin was dose dependent, being maximal at $2 \mathrm{nM}$. Approximately $4 \%$ of the cells became insulin positive at this concentration, and mRNAs for insulin and PP were detected. When AR42J cells were incubated with a combination of betacellulin and activin $\mathrm{A}, \sim 10 \%$ of the cells became insulin positive. Morphologically, the insulin-positive cells were composed of two types of cells: neuron-like and roundshaped cells. Immunoreactive PP was found in the latter type of cells. The mRNAs for insulin, PP, glucose transporter 2, and glucokinase, but not glucagon, were detected. Depolarizing concentration of potassium, tolbutamide, carbachol, and glucagon-like peptide-1 stimulated the release of immunoreactive insulin. These results indicate that betacellulin and activin A convert amylase-secreting AR42J cells into cells secreting insulin. AR42J cells provide a model system to study the formation of pancreatic endocrine cells. (J. Clin. Invest. 1996. 97:1647-1654.) Key words: differentiation - glucagon - pancreatic polypeptide - glucokinase $\bullet$ glucose transporter 2
\end{abstract}

\section{Introduction}

The origin and formation of endocrine cells in pancreatic islets have been extensively studied $(1,2)$. Besides the synthesis of islet hormones, pancreatic endocrine cells express many features characteristic of neuronal cells during development. For example, pancreatic islet cells express several neuroectoder-

Address correspondence to Itaru Kojima, M.D., Institute for Molecular and Cellular Regulation, Gunma University, Maebashi 371, Japan. Phone: 81-272-20-8835; FAX: 81-272-20-8893.

Received for publication 12 October 1995 and accepted in revised form 19 January 1996.

J. Clin. Invest.

(C) The American Society for Clinical Investigation, Inc.

0021-9738/96/04/1647/08 \$2.00

Volume 97, Number 7, April 1996, 1647-1654 mal marker proteins including neuron-specific enolase (3), synaptophysin (4), and tyrosine hydroxylase (5). These cells also have excitable membranes and express voltage-dependent sodium channels and calcium channels (6). Furthermore, when pancreatic $\beta$ cells are cultured, they extend neurite-like processes which contain neurofilament, a marker protein of neurons (7). Despite the fact that pancreatic endocrine cells resemble neurons in many respects, they are considered to be of endodermal origin (1). It is accepted that endocrine cells in the pancreas arise from epithelial cells in pancreatic duct $(5,8)$. Yet, there is only limited information as to the processes of endocrine determination and the subsequent formation of different types of endocrine cells. Glucagon is thought to be the first hormone detected in the developing pancreas $(5,9)$. It is postulated that cells containing glucagon are precursors of various types of islet endocrine cells (10). Reverse transcription-PCR (RT-PCR $)^{1}$ has detected the mRNAs for glucagon and insulin in endocrine precursor cells at embryonal day 9.5 (E 9.5) (11). On the other hand, immunoreactive pancreatic polypeptide (PP) has been detected at E10.5 in the mouse and endocrine precursor cells found in epithelium of pancreatic duct express $\mathrm{PP}$ as well as glucagon or insulin (12). Anti-PP antibody might cross-react with neuropeptide Y (NPY) and/or peptide YY $(13,14)$. When cells transcribing glucagon, insulin, or PP genes are destroyed through the promoter-targeted expression of the diphtheria toxin A chain, embryos lacking PP gene-expressing cells also lack those containing insulin and somatostatin (15). In contrast, embryos lacking glucagon- or insulin-containing cells do not exhibit alterations in the development of the nontargeted islet cell types (16). These results suggest the importance of PP-containing cells in the differentiation of endocrine cells in the islets. Nevertheless, the mechanisms that regulate formation and differentiation of the pancreatic hormone-producing cells still remain largely undetermined.

Rat pancreatic AR42J cells are derived from a chemically induced pancreatic tumor (16). These cells possess both exocrine and neuroendocrine properties. Thus, AR42J cells secrete amylase and other digestive enzymes (16). As neuroendocrine markers, these cells express synaptophysin and neurofilament, take up and release $\gamma$-aminobutyric acid, and possess an excitable membrane (16). When exposed to dexamethasone, they become acinar-like cells (17). We have shown recently that, when treated with activin $A$, a member of the TGF- $\beta$ supergene family (18), AR42J cells extend neurites (19). Thus, activin-treated AR42J cells have the cytoskel-

1. Abbreviations used in this paper: $\left[\mathrm{Ca}^{2+}\right]_{\mathrm{c}}$, cytoplasmic free calcium concentration; E, embryonal day; GLP-1, glucagon-like peptide-1; GLUT2, glucose transporter 2; NPY, neuropeptide Y; PP, pancreatic polypeptide; RT, reverse transcription. 


\begin{tabular}{|c|c|c|c|c|c|}
\hline gene & sense primer & antisense primer & $\begin{array}{c}\text { size of } \\
\text { product (bp) }\end{array}$ & $\begin{array}{c}\text { nucleotide } \\
\text { number }\end{array}$ & $\begin{array}{c}\text { Gen Bank } \\
\text { accession number }\end{array}$ \\
\hline insulin (I and II) & $\begin{array}{l}\text { TGCCCAGGCTTTTGTC- } \\
\text { AAACAGCACCTT }\end{array}$ & $\begin{array}{l}\text { CTCCAGTGCCAAG- } \\
\text { GTCTGAA }\end{array}$ & 187 & $\begin{array}{l}4244-4430 \\
1177-1862\end{array}$ & $\begin{array}{l}\text { J } 00747 \\
\text { J } 00748\end{array}$ \\
\hline glucagon & $\begin{array}{l}\text { GTGGCTGGATTGTTTG- } \\
\text { TAATGCTG }\end{array}$ & $\begin{array}{l}\text { CGGTTCCTCTTGGT- } \\
\text { GTTCATCAAC }\end{array}$ & 236 & $\begin{array}{l}59-132 \\
89-250\end{array}$ & $\begin{array}{l}\text { K } 02809 \\
\text { K } 02810\end{array}$ \\
\hline PP & $\begin{array}{l}\text { TGAACAGAGGGCTCA- } \\
\text { ATACGAAAC }\end{array}$ & $\begin{array}{l}\text { AGACAGAAGGGAG- } \\
\text { GCTACAAATCC }\end{array}$ & 214 & $2198-2692$ & M 18207 \\
\hline GK & $\begin{array}{l}\text { AAGGGAACAACATCG- } \\
\text { TAGGA }\end{array}$ & $\begin{array}{l}\text { CATTGGCGGTCTTCA- } \\
\text { TAGTA }\end{array}$ & 136 & $\begin{array}{r}47-96 \\
1-80\end{array}$ & $\begin{array}{l}\text { M } 24947 \\
\text { M } 24948\end{array}$ \\
\hline GLUT2 & $\begin{array}{l}\text { TTAGCAACTGGGTCTG- } \\
\text { CAAT }\end{array}$ & $\begin{array}{l}\text { GGTGTAGTCCTACA- } \\
\text { CTCATG }\end{array}$ & 343 & $1424-1766$ & J 01345 \\
\hline$\beta$-actin & $\begin{array}{l}\text { CGTAAAGACCTCTATG- } \\
\text { CCAA }\end{array}$ & $\begin{array}{l}\text { AGCCATGCCAAATG- } \\
\text { TCTCAT }\end{array}$ & 349 & $2748-3220$ & J 00691 \\
\hline
\end{tabular}

etal architecture characteristic of neurites. In addition, the cytoplasmic free calcium concentration $\left(\left[\mathrm{Ca}^{2+}\right]_{c}\right)$ in the activin-treated cells is elevated by tolbutamide, suggesting the expression of the sulfonylurea receptor and the ATP-sensitive potassium channel ( $\mathrm{K}_{\mathrm{ATP}}$ channel) (19). Moreover, mRNA for the $\alpha_{1}$ subunit of the neuroendocrine/ $\beta$ cell-type voltagedependent calcium channel is expressed in activin-treated cells. Activin-treated AR42J cells thus possess the neuroendocrine properties common to islet cells. Taken together, AR42J cells have the potential to differentiate into both exocrine and neuroendocrine cells in the pancreas, and we have postulated that AR42J cells would provide a good in vitro model system with which to study the differentiation of neuroendocrine cells in islets (19). Nevertheless, activin-treated cells do not synthesize islet hormones such as insulin (19), a hallmark of islet endocrine cells. If activin commits AR42J cells to differentiate into endocrine cells, they should express islet hormones under some conditions. Here, we investigated this possibility. The results indicated that betacellulin and activin A act synergistically to convert AR42J cells to insulin-producing cells.

\section{Methods}

Materials. Recombinant human activin A (20) and activin-free FCS were provided by Dr. Y. Eto (Central Research Laboratory, Ajinomoto Inc., Kawasaki, Japan). Recombinant human deglycosylated betacellulin was prepared as described (20a). EGF was obtained from Collaborative Research (Lexington, MA), TGF- $\alpha$ was from Peninsular Laboratory (Belmont, CA), and gastrin, glucagon-like peptide-1 (GLP-1), and NPY were from Peptide Institute (Osaka, Japan). Carbacol was from Sigma Chemical Co. (St. Louis, MO).

Cell culture. AR42J cells were cultured in DME containing 20 $\mathrm{mM}$ Hepes/ $\mathrm{NaOH}, \mathrm{pH} 7.4,5 \mathrm{mM} \mathrm{NaHCO}$, and $10 \%$ activin-free FCS (19) at $37^{\circ} \mathrm{C}$ under a humidified condition of $95 \%$ air and $5 \%$ $\mathrm{CO}_{2}$. To measure $\left[\mathrm{Ca}^{2+}\right]_{c}$, cells were grown on glass coverslips. AR42J-B20 cells are subclones of AR42J cells, and $>95 \%$ of them convert into insulin-producing cells after the treatment with betacellulin and activin A. Glucose responsive MIN6 insulinoma cells (21) were cultured in DME containing 10\% FCS and $25 \mathrm{mM}$ glucose.

Antibodies. Polyclonal rabbit anti-bovine PP antibody was provided by Dr. T. Takeuchi of Institute for Molecular and Cellular Regulation, Gunma University (Maebashi, Japan). Polyclonal rabbit antiglucagon antibody was provided by Dr. Ohneda of Tohoku University (Sendai, Japan). Anti-human salivary amylase antibody was purchased from Sigma Chemical Co. Polyclonal anti-NPY antibody was obtained from Peptide Institute. Other commercially available antibodies were indocarbocyanine-conjugated donkey anti-rabbit IgG (Jackson Immuno Research Laboratories, West Grove, PA), indocarbocyanine-conjugated donkey anti-guinea pig IgG (Jackson Immuno Research Laboratories) and tetramethylrhodamine isothianate-conjugated goat anti-mouse IgG (Cappel Laboratories, Turnhout, Belgium).

Immunofluorescence microscopy. Cells were cultured on noncoated glass coverslips at a density of $10^{5}$ cells $/ \mathrm{ml}$. Cells were fixed with $3 \%$ paraformaldehyde in PBS, treated with $0.1 \%$ (vol/vol) Triton X-100 in PBS for 5 min, and incubated sequentially with Blocking Ace (Morinaga, Tokyo, Japan), first antibody, and indocarbocyanineconjugated donkey anti-rabbit IgG or indocarbocyanine-conjugated donkey anti-guinea pig IgG. The cells were examined under a light microscope (Axiophoto; Carl Zeiss, Inc., Thornwood, NY).

Analysis of $m R N A$ by reverse transcription-PCR. mRNA was extracted by using the Quick Prep Kit (Pharmacia LKB Biotechnology, Inc., Piscataway, NJ). Messenger RNA obtained from rat pancreatic islets was used as a control template. mRNA samples were pretreated with DNase to remove any traces of contamination of genomic DNA. First-stranded cDNA was synthesized by using Preamplification System for First Strand cDNA Synthesis kit (GIBCO BRL, Gaithersburg, MD). To confirm no contamination of genomic DNA, samples without reverse transcriptase treatment were prepared. Oligonucleotide primers used in this study are shown in Table I (22). The reactions were conducted in a DNA Thermal Cycler (Perkin-Elmer Corp., Norwalk, CT) in the presence of $\left[\alpha{ }^{32} \mathrm{P}\right] \mathrm{dCTP}$ under the following conditions: for insulin, glucokinase, and glucose transporter 2 (GLUT2), denaturation at $94^{\circ} \mathrm{C}$ for $1 \mathrm{~min}$, annealing and extension at $65^{\circ} \mathrm{C}$ for $2 \mathrm{~min}$, and for glucagon, $\mathrm{PP}$, and $\beta$-actin, denaturation at $94^{\circ} \mathrm{C}$ for $30 \mathrm{~s}$, annealing at $60^{\circ} \mathrm{C}$ for $30 \mathrm{~s}$, and extension at $72^{\circ} \mathrm{C}$ for $45 \mathrm{~s}$. The number of cycles was 25 except 23 cycles for glucokinase and 20 cycles for $\beta$-actin (19). The products were separated on a $5 \%$ polyacrylamide gel, which was then dried and exposed to x-ray film.

Measurement of cytoplasmic free calcium concentration. Cells were grown on glass coverslips and were treated with activin A and/or betacellulin. They were then loaded with a calcium-sensitive fluorescent dye fura-2 (23) by incubating with $2 \mu \mathrm{M}$ fura-2/acetoxymethylester for $30 \mathrm{~min}$ at room temperature. The fura-2-loaded cells were examined under a fluorescence microscope, and fluorescence from a single cell was monitored as described previously (19). The ratio of the emissions generated by excitation at 340 and $380 \mathrm{~nm}$ (340/380 ratio) was used as an index of $\left[\mathrm{Ca}^{2+}\right]_{\mathrm{c}}$.

Measurement of DNA synthesis. DNA synthesis was assessed in two ways. First, $\left[{ }^{3} \mathrm{H}\right]$ thymidine incorporation was measured. Cells were incubated for $24 \mathrm{~h}$ with various agents and $2 \mu \mathrm{Ci} / \mathrm{ml}\left[{ }^{3} \mathrm{H}\right]$ thymi- 
dine and $\left[{ }^{3} \mathrm{H}\right]$ thymidine incorporation into TCA-precipitable materials was measured as described by McNiel et al. (24). Nuclear labeling was measured by using bromodeoxyuridine (BrdU) (Amersham International, Bucks, UK) as described (25).

Measurement of amylase content. To measure the amylase content, the cells were washed with ice-cold PBS, scraped off into $1 \mathrm{ml}$ of buffer containing $50 \mathrm{mM} \mathrm{NaH}_{2} \mathrm{PO}_{4}$ and $50 \mathrm{mM} \mathrm{NaCl}, \mathrm{pH} 6.9$, and were sonicated using a probe-type sonicator for $30 \mathrm{~s}$ at $4^{\circ} \mathrm{C}$. Amylase activity released was measured as described elsewhere (26).

Measurement of immunoreactive insulin. Cells were seeded at a density of $4 \times 10^{5}$ cells $/ \mathrm{ml}$ in a 24-well plate and incubated for $3 \mathrm{~d}$ with $1 \mathrm{nM}$ betacellulin and $2 \mathrm{nM}$ activin A. The cells were washed with DME and were incubated for $60 \mathrm{~min}$ in Krebs-Ringer bicarbonate buffer containing $5.5 \mathrm{mM}$ glucose (KRB buffer) in the presence of various stimulators. The medium was kept at $-20^{\circ} \mathrm{C}$ until the assay for immunoreactive insulin. The protein content of the cells was measured by the method of Bradford (27). Insulin release from MIN6 cells was evaluated similarly.

A time-resolved immunofluorometric assay system (TR-IFMA) (28) for rat insulin, which was sensitive enough for the present study, was established using anti-porcine insulin antibodies raised in guinea pigs in Biosignal Research Center of the Institute for Molecular and Cellular Regulation (Gunma University).

Insulin antibody fractions were obtained by protein A affinity chromatography. Labeling of the antibody with Eu was carried out using Eu-labeling set (Pharmacia LKB Biotechnology) as follows: To $1 \mathrm{mg}$ of antibody dissolved in $300 \mu \mathrm{l}$ of $50 \mathrm{mM}$ carbonate buffer containing $0.9 \% \mathrm{NaCl}, \mathrm{pH} 9.8$, was added Eu-labeling solution $(0.28 \mathrm{mg}$ Eu- $N^{1}$ [ $p$-isothiocyanatobenzyl]-diethylenetriamine- $N^{1}, N^{2}, N^{3}$-tetraacetic acid in $100 \mu \mathrm{l}$ water) and allowed to stand for $20 \mathrm{~h}$ at room temperature. The reaction mixture was applied on a Sephacryl S-300 column $(1.0 \times 40 \mathrm{~cm})$, and eluted with an elution buffer containing 50 $\mathrm{mM}$ Tris- $\mathrm{HCl}, 0.1 \% \mathrm{NaCl}$, and $0.05 \% \mathrm{NaN}_{3}, \mathrm{pH}$ 7.8. Eu-labeled antibody fraction obtained was refrigerated until use.

Microtiter strips with 12 wells (Labosystem, Helsinki, Finland) were coated with antiinsulin antibody solution in $50 \mathrm{mM} \mathrm{K} \mathrm{KPO}_{4}$ containing $0.05 \% \mathrm{NaN}_{3}(20 \mu \mathrm{g}$ antibody $/ \mathrm{ml}, 200 \mu \mathrm{l}$ to each well) for overnight. The plates were washed three times with wash solution containing $0.9 \% \mathrm{NaCl}, 0.02 \%$ Tween 20 , and $0.05 \% \mathrm{NaN}_{3}$ using a plate washer (Wallac Delfia Platewash; Pharmacia), then added with blocking solution containing $50 \mathrm{mM} \mathrm{Na} \mathrm{HPO}_{4}, 0.1 \%$ BSA $(300 \mu \mathrm{l}$ to each well), and stored at $4^{\circ} \mathrm{C}$ until use.

Before assay, the antibody-coated plates were washed four times. $150 \mu \mathrm{l}$ of assay buffer containing $50 \mathrm{mM}$ Tris- $\mathrm{HCl}, 0.5 \%$ BSA, $0.05 \%$ bovine $\gamma$-globulin, $0.001 \%$ Tween $40,20 \mu \mathrm{M}$ diethylenetriaminopentaacetic acid, and $0.05 . \% \mathrm{NaN}_{3}, \mathrm{pH} 7.8$, and $50 \mu \mathrm{l}$ of standard insulin solution (rat insulin standard; Linco, St. Charles, MO) in assay buffer or sample solution were placed in these wells, then the plates were shaken in a plate shaker (Wallac Plates Shake; Pharmacia) for $1.5 \mathrm{~h}$ at room temperature. The plates were washed four times, $200 \mu \mathrm{l}$ of Eulabeled antibody solution diluted with the assay buffer at a concentration of $1 \mu \mathrm{g} / \mathrm{ml}$ was added, and then the plates were shaken for a further $1.5 \mathrm{~h}$. After washing six times, $200 \mu \mathrm{l}$ of enhancement solution consisting of $15 \mu \mathrm{M}$ 2-naphthoyltrifluoroacetone, $50 \mu \mathrm{M}$ tri(n-octyl) phosphine oxide and $1 \%$ Triton $\mathrm{X}-100$ in $100 \mathrm{mM}$ acetic acid-potassium hydrogen phthalate buffer, $\mathrm{pH} 3.2$, was added to each well, and shaken for $5 \mathrm{~min}$. Time-resolved fluorometry was carried out using an Arcus 1230 fluorometer (Pharmacia-Wallac).

The least detectable amount of rat insulin in this assay method was $1.5 \mathrm{pg} /$ well. Intraassay coefficient of variation was $4.3 \%$, while that of interassay was $10.4 \%$. When 28 rat serum samples were measured by the present TR-IFMA and RIA, relationship of their assay results was: $(T R-I F M A)=1.21 \times(R I A)+0.19(\mathrm{ng} / \mathrm{ml}), r=0.983$.

\section{Results}

Effects of activin $A$ on the expression of pancreatic polypeptide. In the first set of experiments, we measured the expres- sion of mRNA for insulin, glucagon, or PP in activin-treated AR42J cells by RT-PCR. Although the mRNA for insulin or glucagon was undetectable, mRNA for PP was detected in activin-treated but not naive AR42J cells (Fig. 1). In naive AR42J cells, mRNA for glucokinase was expressed whereas mRNA for GLUT2 was not. In contrast, mRNA for GLUT2 was detected in cells treated with activin A (Fig. 1). When activin-treated cells were stained with anti-PP antibody, PP-positive cells were observed. Fig. $2 \mathrm{~A}$ shows the morphology of PPpositive cells. Pretreatment of the antibody with PP abolished the immunostaining. Activin-treated cells were NPY-negative when stained with anti-NPY antibody. PP immunoreactivity was evident in cells after $2 \mathrm{~d}$ in the presence of activin $\mathrm{A}$, when morphology of the cells began to change. The PP-positive cells were still round. The number of PP-positive cells was maximal $3 \mathrm{~d}$ after the treatment and $26.8 \pm 3.3 \%$ (means $\pm \mathrm{SE}, n=4$ ) of the cells were PP-positive. The number of PP-positive cells declined thereafter as cells extended neurite-like processes. After $10 \mathrm{~d}$, activin-treated cells extended long processes, and PP immunoreactivity disappeared. Thus, activin transiently induced PP-positive cells.

Effect of betacellulin on the expression of insulin. We then examined the ability of various agents to convert AR42J cells into insulin-positive cells. Cells were treated for $5 \mathrm{~d}$ with various factors including EGF, TGF- $\alpha$, fibroblast growth factors, insulin-like growth factors, gastrin, cholecystokinin, and TGF- $\beta$. Immunocytochemistry was then performed using antiinsulin antibody. Among the various factors tested, betacellulin, a growth factor originally isolated from the conditioned medium of insulin-producing $\beta$ cell carcinoma ( $\beta$ TC) cells (29), induced

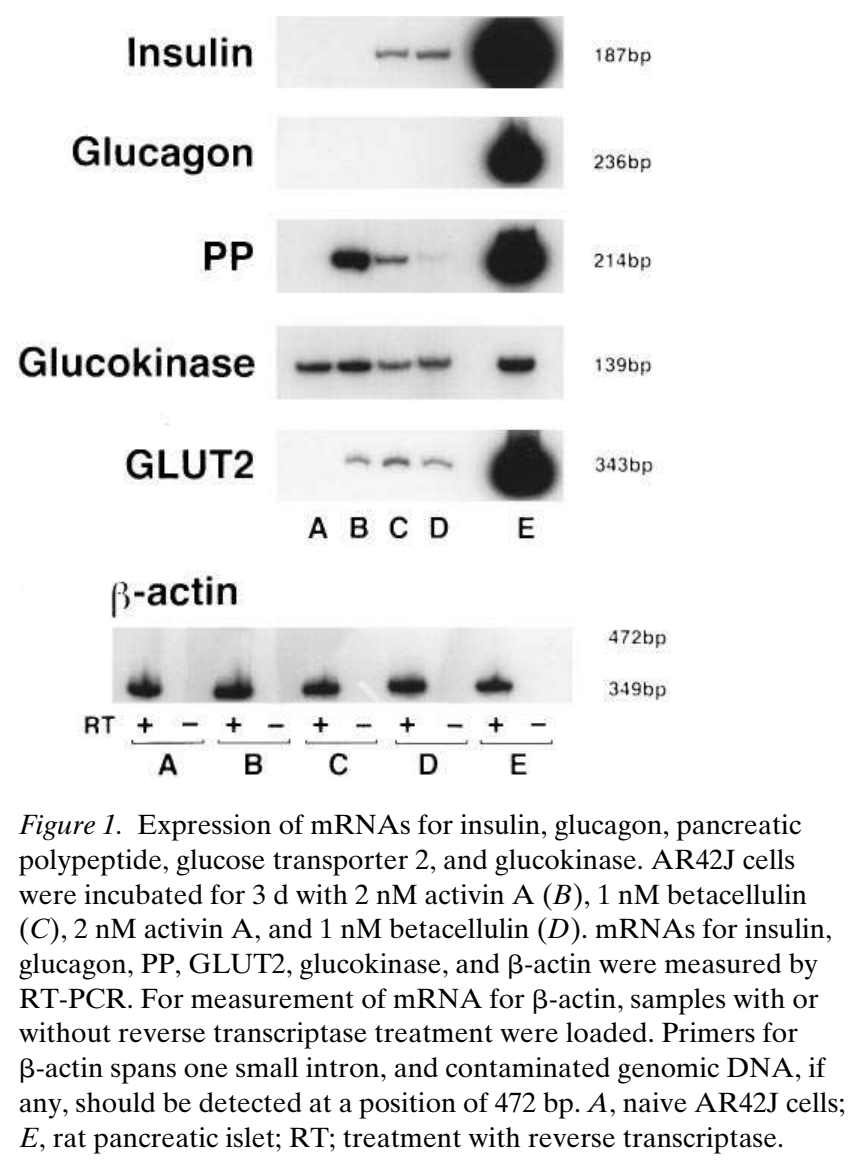



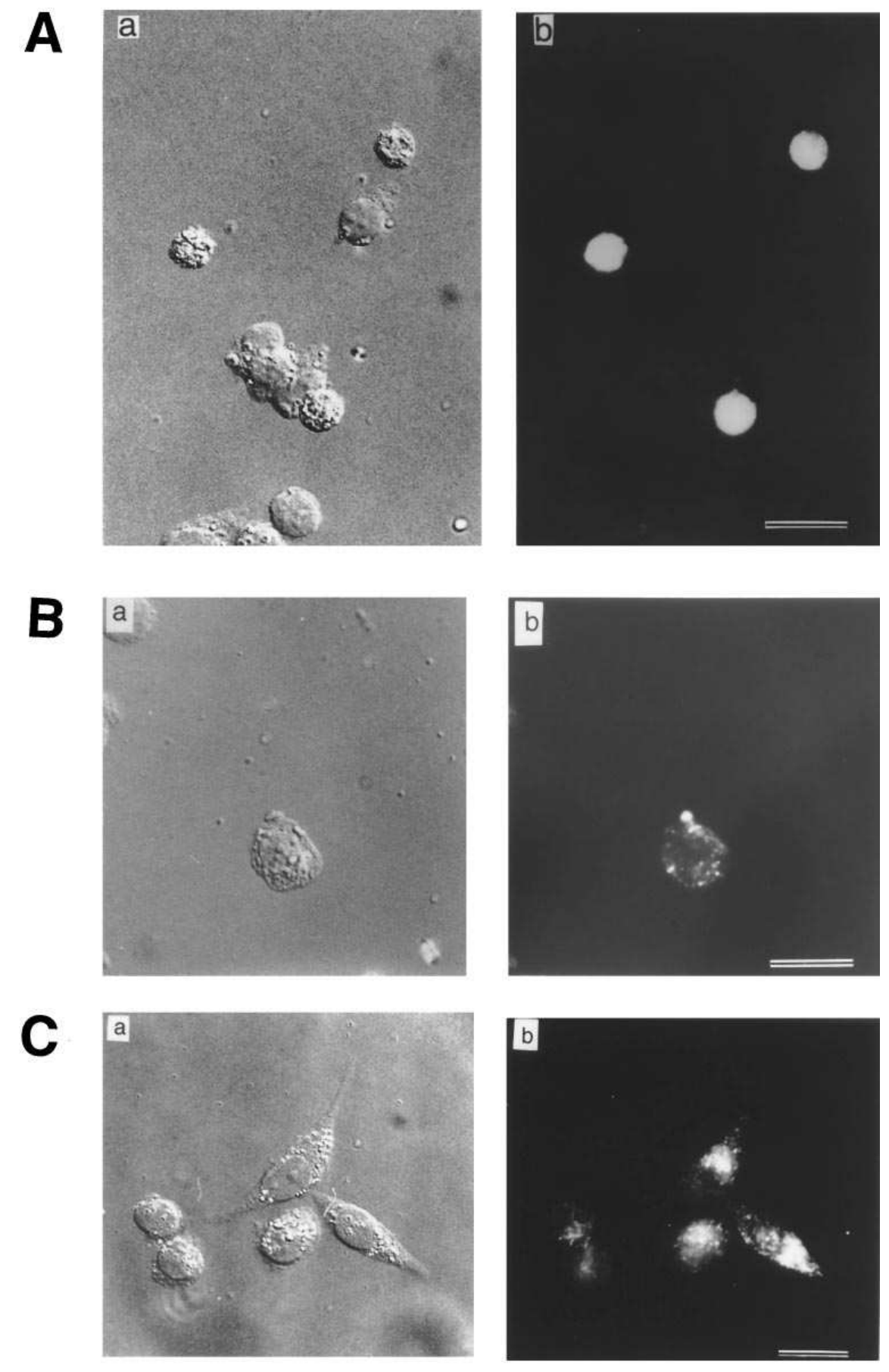

Figure 2. Morphology and immunocytochemistry of AR42J cells treated with activin $\mathrm{A}$ and/or betacellulin. Cells were incubated for $3(A)$ or $5 \mathrm{~d}(B$ and $C)$ with $2 \mathrm{nM}$ activin $\mathrm{A}(A), 1 \mathrm{nM}$ betacellulin $(B)$, or a combination of activin A and betacellulin (C). Cells were stained with anti-PP antibody $(A)$ or anti-insulin $(B$ and $C$ ) antibody. $(a)$ shows the Nomarski image of the same area. Bar, $20 \mu \mathrm{m}$.

a few insulin-positive cells. Fig. $2 B$ shows a typical insulin-positive cell found in betacellulin-treated AR42J cells. The round insulin-positive cells grew singly, whereas insulin-negative cells formed clusters. Exposing the antibody with excess insulin abolished the staining. Neither EGF nor TGF- $\alpha$ reproduced the effect of betacellulin. It is reported that the transgenic mouse expressing both TGF- $\alpha$ and gastrin exhibits enhanced islet neogenesis (30). We also tested the effect of gastrin in the presence or absence of various concentrations of TGF- $\alpha$, but the results were negative. In some solitary betacellulin-treated cells, immunoreactive PP was also detected, whereas immunoreactive glucagon was not (data not shown). PP-positive cells were NPY negative when stained with anti-NPY anti- body, and the number of PP-positive cells was slightly greater than that of the insulin-positive cells. The insulin-positive cells also contained PP while some cells contained PP alone. Fig. 3 $A$ demonstrates the dose-response relationship of the betacellulin effect on the induction of insulin- and PP-positive cells. The effect of betacellulin was dose dependent, and the effect was maximal at $2 \times 10^{-9} \mathrm{M}$. At this concentration, $\sim 4 \%$ of the cells were insulin positive. To determine whether or not betacellulin-treated cells actually synthesize insulin and PP, we measured the expression of mRNA for insulin and PP by RTPCR. As shown in Fig. 1, the mRNA for insulin was detected in betacellulin-treated cells but not in naive AR42J cells. Similarly, the mRNA for PP was detected in betacellulin-treated 

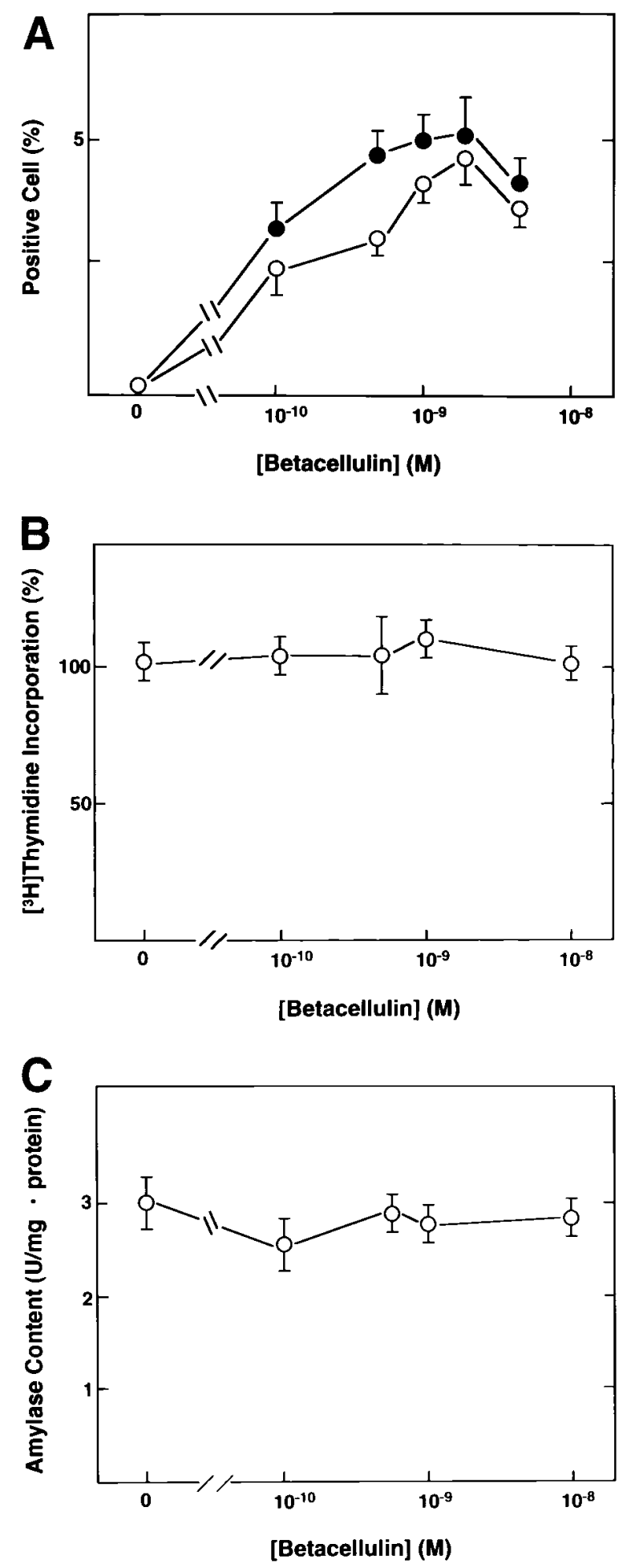

Figure 3. Dose-response relationship for the effect of betacellulin. AR42J cells were incubated for $5 \mathrm{~d}$ in DME containing various concentrations of betacellulin, and the number of insulin- and PP-positive cells $(A)$, DNA synthesis $(B)$, and amylase content $(C)$ were measured. For measurement of insulin- and PP-positive cells, the cells were stained with antiinsulin antibody and anti-PP antibody. The numbers of insulin-positive cells $(\bigcirc)$ and PP-positive cells $(\bullet)$ were counted $(A)$. Values are the means \pm SE for four experiments. but not in naive cells. In contrast, mRNA for glucagon was not detected in betacellulin-treated cells. mRNAs for glucokinase and GLUT2 were expressed in betacellulin-treated cells. To assess the expression of the sulfonylurea receptor and the $\mathrm{K}_{\mathrm{ATP}}$ channel in betacellulin-treated cells, we measured the changes in $\left[\mathrm{Ca}^{2+}\right]_{\mathrm{c}}$ in response to tolbutamide. Tolbutamide binds to the sulfonylurea receptor, inhibits $\mathrm{K}_{\mathrm{ATP}}$ channel activity, depolarizes the plasma membrane, augments calcium entry via voltage-dependent calcium channel and thereby increases $\left[\mathrm{Ca}^{2+}\right]_{\mathrm{c}}$ (19). As shown in Fig. 4, an insulin-positive cell, which was confirmed by subsequent immunocytochemistry, responded to tolbutamide in terms of $\left[\mathrm{Ca}^{2+}\right]_{\mathrm{c}}$. In contrast, cells in clusters, which were insulin negative, did not respond to tolbutamide. We then examined the effect of betacellulin on DNA synthesis in AR42J cells. As shown in Fig. 3 B, betacellulin did not affect DNA synthesis in most of AR42J cells. When DNA synthesis in each cell was assessed by measuring the nuclear labeling of BrdU, BrdU-positive cells were found in clusters of cells whereas nuclear labeling was not detected in insulin-positive solitary cells (data not shown). Fig. $3 C$ shows the effect of betacellulin on the amylase content of AR42J cells. Betacellulin did not significantly alter the amylase content in AR42J cells. Immunocytochemistry revealed that clusters of cells, which did not express immunoreactive insulin, expressed amylase, whereas solitary cells, which expressed insulin, did not (data not shown).

Effect of a combination of betacellulin and activin A. These results suggested that betacellulin converted a portion of AR42J cells into insulin-positive cells. We then investigated the interaction of activin $\mathrm{A}$ and betacellulin. As described above, activin A did not induce insulin-positive cells by itself. When cells were incubated for $5 \mathrm{~d}$ with $1 \times 10^{-9} \mathrm{M}$ betacellulin, $\sim 3 \%$ of the cells became insulin-positive (Fig. $5 A$ ). When cells were treated with a combination of $1 \times 10^{-9} \mathrm{M}$ betacellulin and $2 \times 10^{-9} \mathrm{M}$ activin $\mathrm{A}, \sim 10 \%$ of them became insulin positive. Again, neither TGF- $\alpha$ nor EGF was effective in the presence of activin $\mathrm{A}$ in inducing insulin-positive cells (Fig. 5 $A)$. Fig. $5 B$ shows the dose-response relationship for the betacellulin effect on the induction of insulin-positive cells measured in the presence of activin A. The effect of betacellulin was maximal at a concentration of $2 \times 10^{-9} \mathrm{M}$, when $\sim 10 \%$ of the cells were insulin positive. Fig. $2 C$ shows the morphology of cells treated with a combination of betacellulin and activin A. Most of the cells exposed to a combination of activin A and betacellulin extended neurite-like processes like those treated with activin A alone but some of them remained round (Fig. 2 $C)$. Immunoreactivity of insulin was detected as dots in both round and spindle cells (Fig. $2 C$ ). Immunoreactivity was not detected when the antibody was preabsorbed with insulin. Like the cells incubated with activin A alone, PP immunoreactivity was detected, whereas glucagon was not detected. Immunoreactivity of PP was detected in round-shaped insulin-containing cells but not in insulin-containing cells with neurite-like processes. Accordingly, the number of PP-positive cells was less than that of insulin-positive cells. mRNA for insulin was detected in the cells incubated with betacellulin and activin A but not in those incubated with activin A alone (Fig. 1). Similarly, mRNAs for glucokinase and GLUT2 were detected in cells exposed to a combination of activin $\mathrm{A}$ and betacellulin, but mRNA for glucagon was not detected.

Secretion of insulin from cells treated with betacellulin and activin $A$. In the next set of experiments, we studied the secre- 


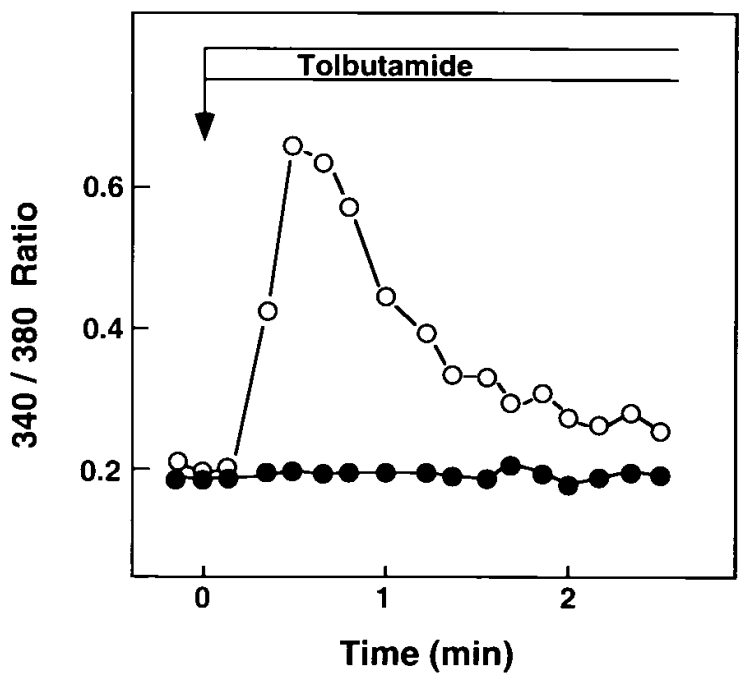

Figure 4. Effect of tolbutamide on $\left[\mathrm{Ca}^{2+}\right]_{\mathrm{c}}$ in betacellulin-induced insulin-positive cell. Cells were incubated for $5 \mathrm{~d}$ with $1 \mathrm{nM}$ betacellulin. $\left[\mathrm{Ca}^{2+}\right]_{\mathrm{c}}$ in an insulin-positive cell $(\bigcirc)$ or negative cell $(\bullet)$ was monitored by measuring the 340/380 ratio of fura- 2 fluorescence. Tolbutamide $(10 \mu \mathrm{M})$ was added as indicated by the arrow.

tion of immunoreactive insulin from AR42J cells treated with the combination of betacellulin and activin A to assess whether or not immunoreactive insulin is released via the regulatory pathway. To this end, we used AR42J-B20 cells, a subclone of AR42J cells. Nearly $100 \%$ of AR42J-B20 cells converted into insulin-positive cells when incubated for $3 \mathrm{~d}$ with activin $\mathrm{A}$ and betacellulin whereas $<10 \%$ of them became insulin positive after the incubation with betacellulin alone. When serially diluted extract of the cell lysates were applied to the insulin assay, immunoreactivity of insulin paralleled the rat insulin standard (data not shown). The secretion of immunoreactive insulin from AR42J-B20 cells exposed to betacellulin and activin A was significantly augmented by tolbutamide, a depolarizing concentration of potassium, carbachol, and GLP-1 (Fig. 6 A). However, elevation of ambient glucose did not augment release of immunoreactive insulin. This was in contrast to the effect of glucose in MIN6 insulinoma cells (Fig. 6 B).

\section{Discussion}

We showed that activin A induces morphological changes in AR42J cells and converts them into neuron-like cells (19). The activin-treated cells exhibited the cytoskeletal organization typical of neurites and expressed several ion channels as found in pancreatic endocrine cells. Based upon these observations, we postulated that activin A commits AR42J cells to differentiate into neuroendocrine cells in the pancreas (19). Activin A induced PP mRNA expression and, in addition, PP immunoreactivity. The primers used for PCR were specific to PP but not to either NPY or peptide YY. Moreover, anti-NPY antibody did not stain activin-treated cells. Therefore, the activintreated cells expressed PP. Since PP is expressed early in the development of pancreatic endocrine cells (12), the results are consistent with the notion that activin A commits AR42J cells to differentiate into cells expressing endocrine traits. In accordance with this idea, mRNA for GLUT2 was expressed in activin-treated cells. The appearance of PP-positive cells was, however, transient. Cells extended long neurites, and the immunoreactivity of PP eventually faded out. These results suggested that activin A by itself is a weak inducer of endocrine cells. We therefore searched for a factor that can synergistically act with activin A to differentiate AR42J cells into islet endocrine cells.

Betacellulin is a growth factor produced in the insulinsecreting tumor cell line, $\beta$ TC-3 (29). The primary structure of betacellulin has homology with EGF, and it is now considered to be a member of the EGF family (29). Betacellulin binds to the EGF receptor (31), and the growth-promoting action of betacellulin is shown to be exerted through the EGF receptor
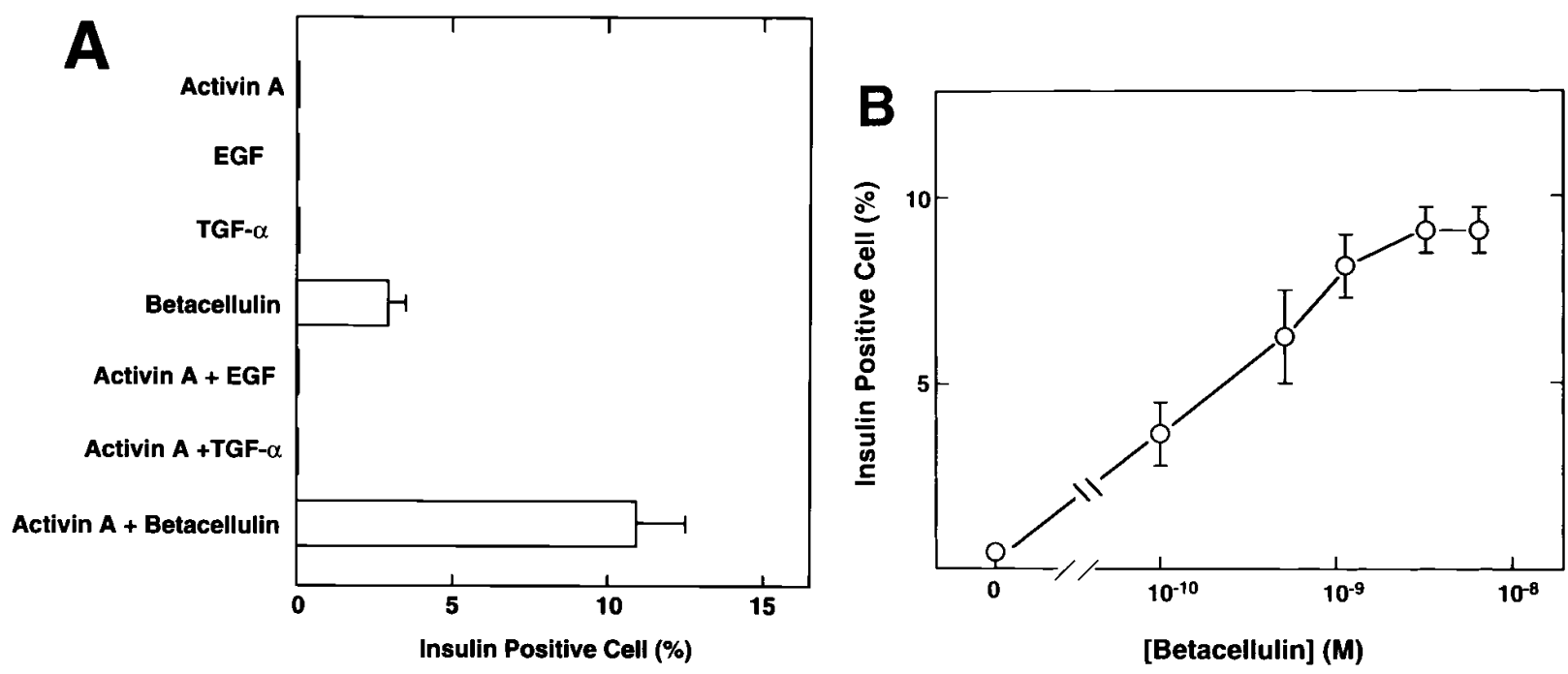

Figure 5. Effect of betacellulin on the induction of insulin-positive cells in the presence of activin A. $(A)$ AR42J cells were incubated for $5 \mathrm{~d}$ with $1 \mathrm{nM}$ betacellulin, $1 \mathrm{nM}$ EGF, or $1 \mathrm{nM}$ TGF- $\alpha$ in the presence and absence of $2 \mathrm{nM}$ activin A. Cells were stained with antiinsulin antibody, and the insulin-positive cells were counted. Values are the means \pm SE for four experiments. (B) AR42J cells were incubated for $5 \mathrm{~d}$ in DME containing various concentrations of betacellulin and $2 \mathrm{nM}$ activin A. The number of insulin-positive cells was then counted. Values are the means \pm SE for four experiments. 


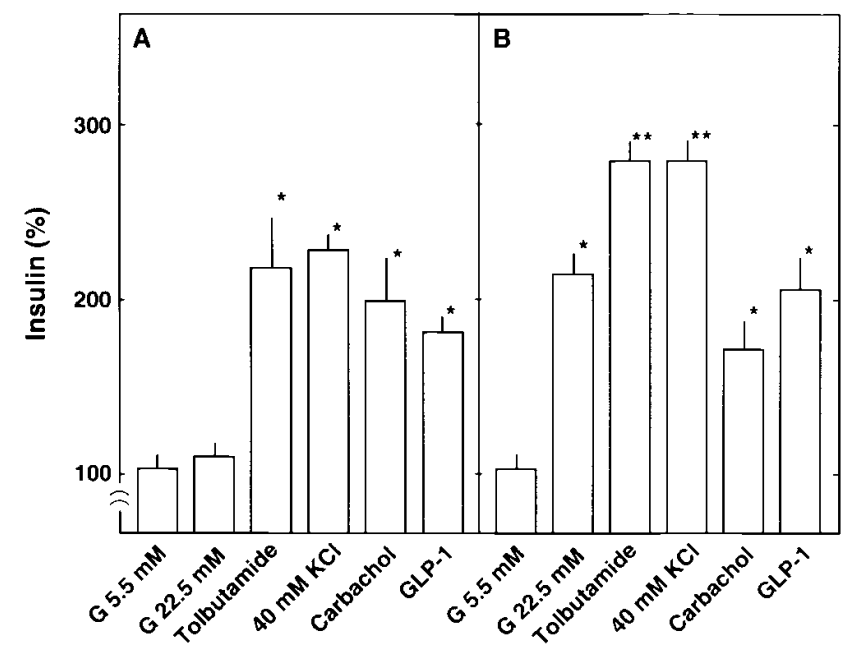

Figure 6. Immunoreactive insulin produced in AR42J-B20 cells treated with betacellulin and activin A and in MIN6 cells. $(A)$ AR42J-B20 cells were incubated for $3 \mathrm{~d}$ in DME containing $1 \mathrm{nM}$ betacellulin and $2 \mathrm{nM}$ activin A. Cells were then incubated for $60 \mathrm{~min}$ in KRB buffer containing either $22.5 \mathrm{mM}$ glucose, $10 \mu \mathrm{M}$ tolbutamide, $40 \mathrm{mM}$ potassium, $100 \mu \mathrm{M}$ carbachol, or $1 \mathrm{nM}$ GLP-1. Insulin output was then measured. Values are the means \pm SE for four experiments. Basal insulin release in KRB buffer was $0.12 \pm 0.05 \mathrm{ng} /$ well per h. $(B)$ MIN6 cells were incubated for $60 \mathrm{~min}$ in KRB buffer containing either $22.5 \mathrm{mM}$ glucose, $10 \mu \mathrm{M}$ tolbutamide, $40 \mathrm{mM}$ potassium, $100 \mu \mathrm{M}$ carbachol, or $1 \mathrm{nM} \mathrm{GLP}-1$, and insulin output was measured. Basal insulin release was $5.6 \pm 0.4 \mathrm{ng} /$ well per $\mathrm{h} . * P<0.05$ vs none analyzed by Student's $t$ test. **P<0.01 vs none.

in fibroblasts (31). Although betacellulin is a growth factor, it did not affect DNA synthesis in most of the AR42J cells. Rather, it converted a few AR42J cells into insulin-producing cells. This effect was not reproduced by either EGF or TGF- $\alpha$ at least in the conditions examined. Hence, the effect of betacellulin in AR42J cells may not be exerted through the EGF receptor. Presumably, betacellulin acts on its own receptor. Although only a few cells responded to betacellulin, they eventually exhibited properties common to those of islet cells: they expressed mRNA for insulin and PP and they responded to tolbutamide in terms of $\left[\mathrm{Ca}^{2+}\right]_{c}$ elevation. The reason for the lack of a response to betacellulin in the majority of the AR42J cells may result from the polyclonal origin of AR42J cells. From a biochemical point of view, it is likely that only a few cells express enough betacellulin receptors. It is also possible that, with the aid of another factor(s), more AR42J cells would respond to betacellulin. In this regard, we examined the interaction of betacellulin and activin A. Fig. 5 shows that the number of insulin-positive cells induced by betacellulin was increased in the presence of activin A. The effects of the two factors were synergistic and the combination of the two factors elicited qualitatively different effects from those elicited by each factor. To our knowledge, this is the first demonstration that amylase-secreting cells convert into insulin-secreting cells in a culture system. These results support our hypothesis that activin A acts on AR42J cells and commits them to differentiate into pancreatic neuroendocrine cells. They also extend the idea in that AR42J cells express insulin and PP in the presence of betacellulin. AR42J cells thus resemble the putative precursor cells present in the pancreatic duct (32).
However, the AR42J cells incubated with activin A and betacellulin differ in some respects from endocrine precursor cells in developing pancreas. For example, although cells incubated with betacellulin and activin A expressed insulin and PP, they did not express glucagon, which is considered to be expressed in endocrine precursor cells of the pancreatic anlage during development (10). Despite the differences, our results provide important information about the differentiation of pancreatic endocrine cells. Firstly, amphicrine pancreatic AR42J cells, which may resemble ductal precursor cells in some respects (32), are in fact capable of differentiating into hormonesecreting cells in the presence of defined factors in culture. These cells provide a simple in vitro experimental system with which to study the regulation of formation and differentiation of pancreatic endocrine cells and to identify the genes involved. Secondly, the factors previously unrecognized as differentiation factors in pancreas, namely, activin A and betacellulin, can differentiate amphicrine AR42J cells into hormoneproducing cells. These factors are expressed in pancreatic islets as well as in endocrine precursor cells of the pancreas during development. For example, immunoreactive activin A is expressed in rat pancreatic islets $(33,34)$ and in endocrine precursor cells in the pancreatic anlage of the rat embryo (35). Specifically, activin-containing cells are found in pancreatic anlage at E12, and cells containing activin A, insulin, and glucagon are found at E13.5 (35). Likewise, betacellulin is expressed in human islet cells of the normal pancreas, in nesidioblastosis cells, and in insulinoma cells (Miyagawa, J., unpublished observation). These observations suggest an in vivo role of activin $\mathrm{A}$ and betacellulin in the formation and/or differentiation of pancreatic endocrine cells. Thirdly, AR42J cells converted to cells expressing PP and insulin but not glucagon. This observation suggests that glucagon-positive cells may not be the obligatory precursors of insulin-positive cells at least in this model system. Instead, the PP-positive cell appears to be a likely candidate for the precursor of insulin-positive cell in this system. In this regard, Herrera et al. (15) reported that $\beta$ cells are markedly reduced when toxigene is expressed in PP-positive cells during development. Collectively, these results suggest a role of PP-positive cells in the formation of insulin-positive cells.

Although AR42J cells are chemically induced tumor cells that originated from an exocrine pancreas (16), the events seen in these cells in vitro are consistent with those in normal cells at least on some occasions. For instance, activin A blocks the dexamethasone-induced differentiation of AR42J cells into acinar-like cells (26). Activin A also blocks the epithelial branching morphogenesis of pancreatic acini in organ culture of the pancreatic anlage (36). In any event, the roles of betacellulin and activin A should be examined in vivo.

In summary, activin A and betacellulin convert amylasesecreting pancreatic AR42J cells into insulin-secreting cells. These cells provide an in vitro experimental system with which to study the formation and differentiation of pancreatic endocrine cells.

\section{Acknowledgments}

We are grateful to Dr. Jun Takeda of the Institute for Molecular and Cellular Regulation, Gunma University for helpful discussion and Kiyomi Ohgi for secretarial assistance. 
The present study was supported by a Grant-in-Aid for Scientific Research from the Ministry of Education, Science and Culture of Japan.

\section{References}

1. Le Douarin, N.M. 1988. On the origin of pancreatic endocrine cells. Cell. 53:169-171.

2. Teitelman, G. 1991. Cellular and molecular analysis of pancreatic islet cell lineage and differentiation. Recent Prog. Horm. Res. 47:259-297.

3. Polak, J.M., S.R. Bloom, and P.J. Marango. 1984. Neuron-specific enolase, a marker for neuroendocrine cells. In Evolution and Tumor Pathology of the Neuroendocrine System. S. Falkmer, R. Hakanson, and F. Sundler, editors. Elsevier Science Publishers, Amsterdam. 51-68.

4. Weidenmann, B., W.W. Franke, C. Kuhn, R. Moll, and V.E. Gould. 1986. Synaptophysin: a marker protein for neuroendocrine cell and neoplasms. Proc. Natl. Acad. Sci. USA. 83:3500-3504.

5. Teitelman, G., and J.K. Lee. 1987. Cell lineage analysis of pancreatic islet cell development: glucagon and insulin cells arise from catecholaminergic precursors present in the pancreatic duct. Dev. Biol. 121:454-466.

6. Ashcroft, F.M., and P. Rorsman. 1991. Electrophysiology of the pancreatic $\beta$-cell. Prog. Biophys. Mol. Biol. 54:87-143.

7. Teitelman, G. 1990. Insulin cells of pancreas extend neurites but do not arise from the neuroectoderm. Dev. Biol. 142:368-379.

8. Pictet, R.L., W.R. Clark, R.H.Williams, and W.J. Rutter. 1972. An ultrastructural analysis of the developing embryonic pancreas. Dev. Biol. 29:436467.

9. Rall, L.B., R.L. Pictet, R.S. Williams, and W.J. Rutter. 1973. Early differentiation of glucagon-producing cells in embryonic pancreas. Proc. Natl. Acad. Sci. USA. 70:3478-3482.

10. Alpert, S., D. Hanahan, and G. Teitelman. 1988. Hybrid insulin genes reveal a developmental lineage for pancreatic endocrine cells and imply a relationship with neurons. Cell. 53:295-308.

11. Gittes, G.K., and W.J. Rutter. 1992. Onset of cell-specific gene expression in the developing mouse pancreas. Proc. Natl. Acad. Sci. USA. 89:11281132.

12. Herrera, P.L., J. Huarte, F. Sanvito, P. Meda, L. Orci, and J.D. Vassalli. 1991. Embryogenesis of the murine endocrine pancreas: early expression of pancreatic polypeptide gene. Development. 113:1257-1265.

13. Teitelman, G., S. Alpert, J.M. Polak, A. Martinez, and D. Hanahan. 1993. Precursor cells of mouse endocrine pancreas coexpress insulin, glucagon and the neural proteins tyrosine hydroxylase and neuropeptide $\mathrm{Y}$ but not pancreatic polypeptide. Development. 118:1031-1039.

14. Upchurch, B.H., G.W. Aponte, and A.B. Leiter. 1994. Expression of peptide YY in all four islet cell types in the developing mouse pancreas suggests a common peptide YY-producing progenitor. Development. 120:245-252.

15. Herrera, P.L., J. Huarte, R. Zufferey, A. Nichols, B. Mermillod, J. Philippe, P. Muniesa, F. Sanvito, L. Orci, and J.D. Vassalli. 1994. Ablation of islet endocrine cells by targeted expression of hormone- promoter-driven toxigenes. Proc. Natl. Acad. Sci. USA. 91:12999-13003.

16. Christophe, J. 1994. Pancreatic tumoral cell line AR42J: an amphicrine model. Am. J. Physiol. 266:G963-G971.

17. Logsdon, C.D., J. Moessner, J.A. Williams, and I.D. Goldfine. 1985. Glucocorticoid increase amylase mRNA level, secretory organelles and secretion in pancreatic acinar AR42J cells. J. Cell Biol. 100:1200-1208.

18. Vale, W., J. Rivier, J. Vaugham, R. McClintock, A. Corrigan, W. Woo, D. Karr, and J. Spiess. 1986. Purification and characterization of FSH-releasing protein from porcine ovarian follicular fluid. Nature (Lond.). 321:776-779.
19. Ohnishi, H., N. Ohgushi, S. Tanaka, H. Mogami, R. Nobusawa, H. Mashima, M. Furukawa, T. Mine, O. Shimada, H. Ishikawa, and I. Kojima 1995. Conversion of amylase-containing rat pancreatic AR42J cells to neuronlike cells by activin A. J. Clin. Invest. 95:2304-2314.

20. Murata, N., K. Onomachi, Y. Eto, H. Shibai, and M. Muramatsu. 1988. Expression of erythroid differentiation factor in Chinese hamster ovary cells. Biochem. Biophys. Res. Commun. 151:230-235.

20a. Seno, M., H. Tada, M. Kosaka, R. Sasada, K. Igarashi, Y. Shing, J. Folkman, M. Ueda, and H. Yamada. 1996. Human betacellulin, a member of the EGF family dominantly expressed in pancreas and small intestine, is fully active in a monomeric form. Growth Factors. In press.

21. Miyazaki, J., K. Araki, E. Yamato, H. Ikegami, T. Asano, Y. Shibasaki, Y. Oka, and K. Yamamura. 1990. Establishment of a pancreatic $\beta$-cell line that retains glucose-inducible insulin secretion. Endocrinology. 127:126-132.

22. Iwashima, Y., A.K. Abiko, S. Seino, J. Takeda, M. Eto, K.S. Polonsky, and I. Makino. 1994. Reduced levels of messenger RNA for calcium channel, glucose transporter-2 and glucokinase are associated with alterations in insulin secretion in fasted rats. Endocrinology. 135:1010-1017.

23. Grynkiewicz, G., and R.Y. Tsien. 1985. A new generation of $\mathrm{Ca}^{2+}$ indicators with greatly improved fluorescence properties. J. Biol. Chem. 260:34403450.

24. McNiel, P.L., M.P. McKenna, and D.L. Taylor. 1985. A transient rise in cytosolic calcium follows stimulation of quiescent cells with growth factors. $J$. Cell Biol. 101:372-379.

25. Kanzaki, M., H. Mogami, H. Shibata, and I. Kojima. 1995. Expression of calcium-permeable cation channel CD20 accelerates progression through $\mathrm{G}_{1}$ phase in Balb/c 3T3 cells. J. Biol. Chem. 270:13099-13100.

26. Yasuda, H., S. Tanaka, H. Onishi, H. Mashima, N. Ogushi, and I Kojima. 1994. Activin A: a negative regulator of amylase secretion and cell proliferation in rat pancreatic acinar AR42J cells. Am. J. Physiol. 267:G220-G226.

27. Bradford, M.M. 1976. A rapid and sensitive method for the quantitation of microgram quantities of protein using the principle of protein-dye binding. Anal. Biochem. 72:248-254.

28. Lovgren, T., I. Hemmia, K. Pettersson, and P. Halonen. 1985. Timeresolved fluorometry in immunoassay. In Alternative Immunoassays. W.P. Collins, editor. John Wiley \& Sons Ltd., New York. 203-217.

29. Shing, Y., G. Christofori, D. Hanahan, Y. Ono, R. Sasada, K. Igarashi, and J. Folkman. 1993. Betacellulin: a mitogen from pancreatic beta cell tumors. Science (Wash. DC). 259:1604-1607.

30. Wang T.C. S. Bonner-Weir, P. S. Oates, M.B. Chulak, B. Simon, G.T. Merlino, E.V. Schmidt, and S.J. Brand. 1993. Pancreatic gastrin stimulates islet differentiation of transforming growth factor- $\alpha$-induced ductular precursor cells. J. Clin. Invest. 92:1349-1356.

31. Watanabe, T., A. Shintani, M. Nakata, Y. Shieng, J. Folkman, K. Igarashi, and R. Sasada. 1994. Recombinant human betacellulin. J. Biol. Chem. 269:9966-9973.

32. Gu, D., M.-S. Lee, T. Krahl, and N. Sarvetnick. 1994. Transitional cells in the regenerating pancreas. Development. 120:1873-1881.

33. Yasuda, H., K. Inoue, H. Shibata, Y. Takeuchi, Y. Eto, Y. Hasegawa, N. Sekine, Y. Totsuka, T. Mine, E. Ogata, and I. Kojima. 1993. Existence of activin A in A- and D-cells of rat pancreatic islet. Endocrinology. 133:624-630.

34. Ogawa, K., K. Ono, M. Kuromatsu, and Y. Hayashi. 1995. Effect of streptozotocin injection on expression of immunoreactive follistatin and $\beta \mathrm{A}$ and $\beta B$ subunits of inhibin/activin in rat pancreatic islets. Eur. J. Endocrinol. 132:363-369.

35. Furukawa, M., Y. Eto, and I. Kojima. 1995. Expression of activin A in fetal rat pancreas. Endocrine J. 42:63-68

36. Ritvos, O., T. Tuuri, M. Eramaa, K. Sainio, K. Hilen, L. Saxen, and S.F. Gilbert. 1995. Activin A disrupts epithelial branching morphogenesis in developing glandular organs of the mouse. Mech. Devel. 50:229-245. 